\title{
Privjesci RimSKe KONJSKe ORME iZ SALONE
}

\author{
SAnJa IvČEvić \\ Arheološki muzej \\ Zrinsko-Frankopanska 25 \\ HR 21000 Split \\ sanja.ivcevic@armus.hr
}

\author{
UDK: 904(497.5 Solin) "652" \\ 904:739.4](497.5 Solin) "652" \\ Izvorni znanstveni članak \\ Original scientific paper \\ Primljeno / Received: 2008-03-04
}

\begin{abstract}
U članku su obrađeni privjesci konjske orme iz Salone, koji pripadaju vremenu 1. i 2. st. Takvi se predmeti često nalaze na području Rimskog Carstva, a uz ukrasnu imali su i simboličku ulogu. Dva obrađena primjerka pripadaju tipu Bishop 2a, a datiraju se u 1. st., šest tipu Bishop 5e, koji traju od sredine 1. do kraja 2. st. Dva su svrstana u tip 10, no pripadaju različitim inačicama: 10c i 10r, obje iz 1. st. Neki se primjerci tipološki nalaze između dvaju tipova, što ne čudi s obzirom na postojanje brojnih radionica takve vrste materijala. To je vjerojatno uzrokovalo i raznolikost izraza i detalja na privjescima, premda postoji izvjesna uniformnost $u$ oblikovanju te još više u načinu ukrašavanja.
\end{abstract}

KLJUČNE RIJEČI: privjesci, rimska konjska orma, Salona

Privjesci vješani na remenje konjske orme, uz ukrasnu su ulogu imali i simboličko značenje. Osim za postizanje efekta raskoši i sjaja, stavljani su na životinju kako bi je zaštitili od bolesti i loših utjecaja, zlih pogleda i nesreće. Oblici privjesaka i motivi kojima su ukrašavani kao što su lunula, šaka stisnuta u figu, falos, vinova loza, ptica, imaju simboličko značenje. Lunula je imala zaštitnu ulogu za nositelja, falos je simbol blagostanja i plodnosti, ali i zaštita od uroka i bolesti, vinova loza je simbol plodnosti, a ptica se u tom kontekstu vezuje uz keltsku ikonografiju boga rata. ${ }^{1}$ Moguće je da su isticani kao oznaka vojne vještine ili dodjeljivani kao oznaka hrabrosti, no vjerojatno i kao neformalne nagrade $u$ internim natjecanjima poput sportskih. ${ }^{2}$ Postoji mišljenje da su ukazivali i na status konjanika, odnosno vojni rang. ${ }^{3}$

Privjesci su izrađivani lijevanjem, a ponekad naknadno ukrašavani urezivanjem, nijeliranjem i premazivanjem kositrom.

$\mathrm{Na}$ remenje su se vješali pomoću falere ili zakovice s ušicom. Lijevane zatvorene ušice na vrhu privjeska umetale su se u zglobni mehanizam na stražnjoj strani falere, dok su se privjesci s otvorenom ušicom vješali provlačenjem kroz petlju falere ili kroz alku koja je zakovicom bila učvršćena na remen. Neukrašene ušice uglavnom su savijane prema natrag, a one s ukrašenim završetcima prema naprijed kako bi nakon vješanja bile vidljive. ${ }^{4}$ Premda predviđeni da vise slobodno s konjske orme, privjesci su ponekad, valjda kako ne bi uznemiravali konja, bili zakovicom pričvršćeni za remen orme, te se na pojedinim primjercima (poput kat. br. 10) vide kružni otvori za zakovicu. ${ }^{5}$

\footnotetext{
${ }^{1}$ M. C. BISHOP, $1987,118$.

${ }^{2}$ A. K. LAWSON, 1978, 152.

${ }^{3}$ A. VOIROL, 2000, 22.
} 
Precizno određivanje mjesta na kojem se privjesak nalazio nije moguće izvan konteksta, pa možemo samo pretpostaviti da su oni širine oko $7 \mathrm{~cm}$ vjerojatno služili kao središnji ukras na čelu ili prsima konja, oni širine oko $5 \mathrm{~cm}$ vješali su se na remenje po tijelu, a oni oko $2 \mathrm{~cm}$ remenje na glavi konja. ${ }^{6}$

Prema Bishopovoj tipologiji ${ }^{7}$ najraniji privjesci javljaju se od augustovskog doba, a traju sve do 2. st. Od druge polovice 2. st. privjesci izlaze iz mode, a njihovo mjesto zauzimaju ukrasne pločice, o čemu svjedoči nedostatak nalaza u vojničkim grobovima, kao i na prikazima na kamenim spomenicima. ${ }^{8}$

Privjesci konjske orme, poput svih predmeta koji su imali ukrasnu ulogu, podliježu i modnim trendovima, te imaju razvijenu tipologiju. Prema Bishopovoj tipologiji svrstani su u 11 osnovnih tipova, koji su podijeljeni u brojne varijante. ${ }^{9}$

Privjesak elipsastog tijela sa završetkom u obliku palmete (kat. br. 1, T. I, 1) pripada tipu Bishop 2, inačici 2a. Uglavnom se datiraju od klaudijevskog vremena pa sve do kraja flavijevskog razdoblja, ${ }^{10}$ no u novije vrijeme pojava im se stavlja u početak 1 . st. ${ }^{11}$ Po sačuvanoj ušici izrađenoj lijevanjem očito je da je privjesak bio obješen za faleru pomoću zgloba. Najsličniji primjerci našemu nađeni su u Badenu, a najbliža poznata analogija je iz Siska. ${ }^{12}$ Blizak salonitanskom je i primjerak iz Tilurija, ${ }^{13}$ kojem je jedina razlika što ima bočne izdanke koji ga konstrukcijski vežu uz tip Bishop 1, no ostale značajke kao središnji ukras u obliku palmete i oblik tijela podudaraju se sa salonitanskim primjerkom, te je povezanost dvaju primjeraka očigledna.

Privjesak elipsoidnog tijela, s lijevanom ušicom i palmetastim završetkom (kat. br. 2, T. I, 2), premda ga izduženi oblik tijela približava tipu Bishop 5, prema osnovnim značajkama pripada tipu Bishop 2a, te ga stoga datiramo kao i prethodni primjerak.

Treći primjerak (kat. br. 3, T. I, 3) pokazuje vezu s tzv. pticolikim privjescima (Bishop 7), kojima se početak proizvodnje stavlja u drugu četvrtinu 1. st. Povezanost se očituje prvenstveno u načinu oblikovanja ušice, koja je savijena prema naprijed i izrađena u obliku stilizirane ptičje glave. Primjerci iz Burnuma i Benkovca ${ }^{14}$ pokazuju sličnost, no njima tijelo nije izduženo do te mjere kao kod salonitanskog, a najbliža analogija salonitanskom je primjerak iz vojnog logora Tilurija u blizini Salone. ${ }^{15}$ Unatoč obliku vrha ušice i oštrijoj liniji tijela naš bi se primjerak mogao svrstati u tip 5e, ${ }^{16}$ koji se datira od sredine 1 . i kroz cijelo 2 . st. ${ }^{17}$ Tipološki se nalazi između navedenih tipova.

Četiri privjeska suzolikog oblika (kat. br. 4-7) pripadaju tipu Bishop 5, inačici 5e. Pojava se tih privjesaka stavlja u klaudijevsko razdoblje, a traju do kraja 2. st. ${ }^{18}$ Prilično su dobro zastupljeni na rimskim lokalitetima. Svi su privjesci ove skupine neukrašeni, a međusobno se razlikuju oblikom pločice. Jedan privjesak (kat. br. 4, T. I, 4) ima izražena ramena i naglo se sužava prema izduženu dnu, drugi je (kat. br. 5, T. I, 5) najširi u gornjem dijelu, treći (kat. br. 6, T. II, 6) je gotovo trokutast, dok je četvrti (kat. br. 7, T. II, 7) najširi u sredini.

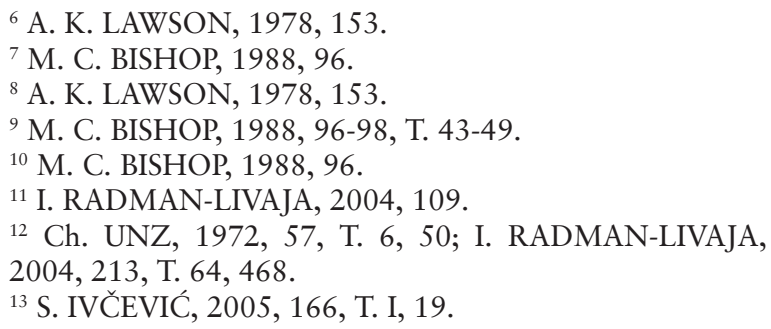

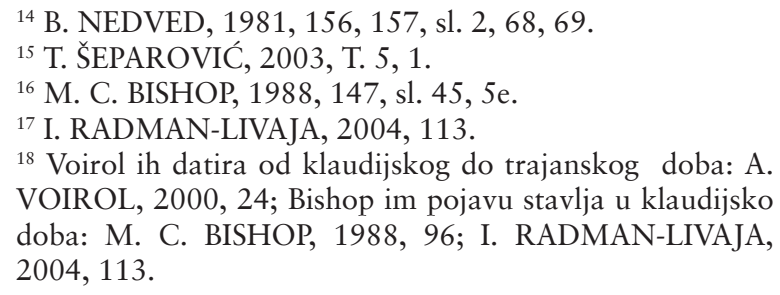
VOIROL, 2000, 24; Bishop im pojavu stavlja u klaudijsko doba: M. C. BISHOP, 1988, 96; I. RADMAN-LIVAJA, 2004, 113. 
Rombični privjesak (kat. br. 8, T. II, 8) ne uklapa se oblikom u potpunosti u Bishopov tip 11, gdje su izdvojeni privjesci ravnih rubova u obliku romba, a interpretiraju se kao dio konjske opreme zahvaljujući prikazu na jednom kamenom spomeniku. ${ }^{19}$ Brojni su u Vindonissi, ${ }^{20}$ a nalaze se i na drugim rimskim lokalitetima. ${ }^{21}$ Primjerak iz Siska, koji konstrukcijski jako podsjeća na salonitanski, datiran je u okvire 1 . st. ${ }^{22} \mathrm{~S}$ obzirom na to da je težište našeg primjerka pomaknuto prema gornjem dijelu pločice, pokazuje vezu s tipom Bishop 5. Slični se primjerci, premda rijetko, ipak mogu naći na rimskim lokalitetima. ${ }^{23}$ Oldenstein sličan primjerak ${ }^{24}$ ne izdvaja od srcolikih s kuglastim završetkom, koje datira kroz cijelo 2. st. ${ }^{25}$

Lunulasti privjesci čest su nalaz na lokalitetima rimskog doba. Javljaju se od vremena cara Augusta, a traju kroz cijelo 2. st. ${ }^{26}$ Iz Salone su sačuvana dva lunulasta privjeska koji pripadaju skupini lunulastih falusoidnih privjesaka, kod Bishopa izdvojenih u posebnu skupinu $10 .{ }^{27}$ Radi se o privjescima s lunulom okrenutom prema gore kojoj su krajevi izrađeni u obliku falusa s jedne, te šake stisnute u figu s druge strane, te s privjeskom s donje strane lunule. Primjerak pod kat. br. $9^{28}$ (T. II, 9) može se odrediti kao tip Bishop 10c, prema donjem dijelu privjeska u obliku reljefno izvedene bikovske glave, s umetcima modrog stakla na mjestu očiju. Takvi su nalazi rijetki, ${ }^{29}$ pripisuju se sjevernoitalskoj radionici i datiraju u prve dvije trećine 1 . st. ${ }^{30}$ Drugom je privjesku (kat. br. 10, T. II, 10) s donje strane lunula s falusom u sredini, na osnovu čega bi ga se moglo svrstati u tip Bishop 10r, premda je naš primjerak stiliziran u većoj mjeri, a i ušica mu je četvrtasta, dok je kod ostalih primjeraka kružna. Ta je inačica također rijetka. ${ }^{31}$ Mali privjesci u obliku falusa često su se nosili oko vrata kao amuleti i bez okolnosti nalaza teško ih je pripisati vojničkoj opremi. ${ }^{32}$ Za lunulaste falusoidne privjeske također nije sasvim jasno jesu li rabljeni za konje za vuču ili vojničke konje, ${ }^{33}$ no često su nalaženi u vojničkom kontekstu osobito oni s kombinacijom fige i falusa. Takvi privjesci imaju snažno apotropejsko značenje. ${ }^{34}$

Obrađeni privjesci, s obzirom na to da su svi dospjeli u Arheološki muzej u Splitu kao slučajni nalazi, isključivo su tipološki izdvojeni kao dijelovi konjske orme. Kako se u Muzeju čuva određen broj takvih predmeta bez podatka o mjestu nalaza, nije moguće utvrditi njihov točan broj.

Neki su tipovi privjesaka bili i u civilnoj i u vojničkoj uporabi, te ih bez preciznih okolnosti nalaza ne možemo uvrstiti u ovu radnju. ${ }^{35}$ To se poglavito odnosi na falusoidne privjeske koji su zbog svoje simbolike i zaštitničke uloge nošeni često oko vrata kao amuleti ili vješani u kućama, te im se eventualna vojnička uporaba može odrediti jedino po kontekstu u kojem su pronađeni.

Salonitanske primjerke možemo svrstati u tri osnovna tipa prema Bishopovoj tipologiji.

${ }^{19}$ M. C. BISHOP, $1988,70,71$, sl. 3.

${ }^{20}$ Ch. UNZ, E. DESCHLER-ERB, 1997, T. 52, 1409-1434; Ch. UNZ, 1972, sl. 6, 62.

${ }^{21}$ Ch. UNZ, 1971, sl. 12, 141.

${ }^{22}$ R. KOŠČEVIĆ, $1991,47$.

${ }^{23}$ Ch. UNZ, 1972, sl. 12, 143.

${ }^{24}$ J. OLDENSTEIN, 1977, T. 30, 210.

${ }^{25}$ J. OLDENSTEIN, 1977, 125.

${ }^{26}$ M. C. BISHOP, $1988,98$.

27 M. C. BISHOP, 1998, 98, posebno izdvaja lunulaste (tip 9), te dvije skupine falusoidnih (tip 6 i 10) - oba naša primjerka pripadaju skupini 10 , ali različitim inačicama.

${ }_{28}$ Ovaj primjerak uvršten je u popis materijala, koji je izradio G. Ulbert, još 1959. godine (R. KOŠČEVIĆ, 1991,
45). Uz salonitanski primjerak navedena su i dva privjeska toga tipa iz Garduna, jedan iz splitskog muzeja, a drugi se čuva u Klagenfurtu. Na tim podacima srdačno zahvaljujem poštovanoj kolegici dr. sc. Remzi Košćević.

${ }^{29}$ Bishop navodi samo jedan primjerak iz Aislingena, M. C. BISHOP, 1998, 155; jedan je pronađen u Vindonissi, Ch. UNZ, G. DESCHLER-ERB, 1997, T. 58, 1630

${ }^{30}$ R. KOŠČEVIĆ, 1991, 45.

${ }^{31}$ M. C. BISHOP, 1998, 156, navodi jedan primjerak.

${ }^{32}$ J. OLDENSTEIN, 1977, 159.

${ }^{33}$ M. C. BISHOP 1988, 98.

${ }^{34}$ M. KOHLERT-NÉMETH, 1988, 66; R. KOŠČEVIĆ, 2003, 30, 32.

${ }^{35}$ R. KOŠČEVIĆ, 2003, 16. 
Dva su primjerka tipa Bishop 2a (kat. br 1, 2) datirana u 1. st., najbolje je zastupljen tip Bishop 5e, kojem pripada šest primjeraka, među kojima je najzanimljiviji privjesak pod kataloškim brojem 3 jer pokazuje vezu s tzv. pticolikim privjescima (Bishop 7), te se tipološki nalazi između tipa Bishop 5 i 7. Za razliku od privjesaka (kat. br. 4-7) koji se svojim značajkama uklapaju u osnovnu shemu tipa 5e, rombični privjesak (kat. br. 8) ipak donekle odskače oblikom tijela. Taj se tip datira nešto kasnije od prethodnog, od sredine 1. st. do kraja 2. st. Tip Bishop 10 zastupljen je s dva primjerka, koji pripadaju različitim inačicama. Onaj s bikovskom glavom (kat. br. 9) (Bishop 10c) analogan je takvim primjercima pronađenim u ostalim dijelovima Carstva, a kako su malobrojni te međusobno slični pretpostavlja se, kao što je već navedeno $\mathrm{u}$ tekstu, proizvodnja u istoj radionici, koja se smješta na područje sjeverne Italije. Lunulasti falusoidni privjesak (kat. br. 10) pokazuje neke specifičnosti u oblikovanju (četvrtasta ušica i jaka stilizacija), te ga smještamo u varijantu kojoj je najsličniji (Bishop 10r). Datirani su u 1. st.

Oblikovanje i način ukrašavanja privjesaka konjske orme odaje izvjesnu uniformnost, te ih je moguće podijeliti u ograničen broj tipova. Istovremeno pokazuju i raznovrsnost izraza, što je očigledno uzrokovano proizvodnjom u brojnim radionicama, a u određenoj mjeri i podrijetlom i tradicijom korisnika. Količinska i tipološka obrada privjesaka, odnosno dijelova konjske opreme sa šireg područja, na primjer provincije Dalmacije, uz spoznaje i promišljanje o kretanju i boravku vojnih jedinica različita etničkog porijekla na tom teritoriju, te eventualno utvrđivanje radioničkih postrojenja za izradu vojničkog materijala, nameće se kao preduvjet za proučavanje vojne povijesti našeg područja.

\section{KATALOG}

1. Inv. br. H 738, privjesak konjske orme, Salona, bronca, nijelo, 1. st. (T. I, 1)

vis. $5,1 \mathrm{~cm}$, šir. 4,6 cm, gornji dio privjeska je elipsoidan, na vrhu je ušica ispunjena željezom, koja je bila dio zgloba pomoću kojeg je privjesak bio obješen odnosno pričvršćen za faleru, donji dio privjeska je u obliku palmete iznad koje je vodoravna traka, sa stražnje strane privjeska je traka koja se proteže od ušice do vodoravne trake.

Literatura: I. RADMAN - LIVAJA, 2004, 213, T. 64, 468; Ch. UNZ, G. DESCHLER-ERB, 1997, T. 50, 1369, 1376; M. MACKENSEN, 1991, 171, sl. 2, 3, 174, sl. 4, 3; E. RABEISEN, 1990, 85, sl. 8, 1, 3; Ch. UNZ, 1972, 57, T. 6, 50; C. BOUBE-PICCOT, 1964, T. IX, 1; E. RITTERLING, 1913, T. XIV, 2.

2. Inv. br. H 817, privjesak konjske orme, Salona, bronca, 1. st. (T. I, 2),

vis. $7,2 \mathrm{~cm}$, šir. $4,2 \mathrm{~cm}$, gornji elipsoidni dio privjeska naglo se sužava, a pri dnu se nalazi okomita trakica ukrašena urezima ispod koje se palmetasto širi, s prednje strane privjesak je premazan kositrom, na vrhu je zatvorena ušica pomoću koje se privjesak vješao.

Literatura: Ch. UNZ, G. DESCHLER-ERB, 1997, T. 50, 1372; T. ŠEPAROVIĆ, 2003, T. 5, 4.

3. Inv. br. H 1224, privjesak konjske orme, Salona, bronca, 1. st. (T. I, 3),

vis. $7 \mathrm{~cm}$, šir. $4,3 \mathrm{~cm}$, privjesak je elipsoidan u gornjem dijelu, postupno se sužava te završava prstenasto, uz rub pločastog dijela urezana je linija. Na vrhu je ušica u obliku stilizirane ptičje glave, izrađena savijanjem prema prednjoj strani privjeska. Na ušici je sačuvan ulomak brončane pločice na koju je privjesak bio pričvršćen.

Literatura: T. ŠEPAROVIĆ, 2003, T. 5, 1; M. FEUGÈRE, M. POUX, 2001, 83, sl. 5, 8; Ch. UNZ, G. DESCHLER-ERB, 1997, T. 54, 1471, T. 55, 1529; B. NEDVED, 1981, 157, sl. 2, 70. 
4. Inv. br. H 1639, privjesak konjske orme, Salona, bronca, druga polovica 1. st., 2. st. (T. I, 4), vis. $3,9 \mathrm{~cm}$, šir. $2,1 \mathrm{~cm}$, listoliko-srcoliki privjesak, donji dio je izdužen i profiliran, ušica za vješanje nije sačuvana.

Literatura: S. JILEK, 2005, 176, sl. 6, 48; R. FAHR, 2005, 128, sl. 8, 2; A. STUPPNER, 2002, 27, sl. 4, 12; Ch. UNZ, G. DESCHLER-ERB, 1997, T. 55, 1511, 1518; R. KOŠČEVIĆ, 1991, T. XIII, 204; I. ČREMOŠNIK, 1984, T. IV, 4.

5. Inv. br. H 1314, privjesak konjske orme, Salona, bronca, druga polovica 1. st., 2. st. (T. I, 5), vis. $3,2 \mathrm{~cm}$, šir. $1,9 \mathrm{~cm}$, listoliko-srcoliki privjesak, postupno se sužava prema donjem dijelu, završava kuglastim ukrasom, od ušice za vješanje ja sačuvan samo dio, s obiju strana vidljivi su ostatci pokositrenja. Literatura: M. FEUGĖRE, M. POUX, 2001, 83, sl. 5, 7; A. VOIROL, 2000, 55, T. 13, 113; Ch. UNZ, G. DESCHLER-ERB, 1997, T. 55, 1514; B. NEDVED, 1981, 157, sl. 2, 71; Ch. UNZ, 1974, 39, sl. 11, 131, sl. 12, 133; G. BEHRENS, 1912, 88, sl. 4, 16.

6. Inv. br. H 818, privjesak konjske orme, Salona, bronca, druga polovica 1. st., 2. st. (T. II, 6), vis. $4,3 \mathrm{~cm}$, šir. $2,3 \mathrm{~cm}$, listoliko-srcoliki privjesak, privjesak je najširi u gornjem dijelu, postupno se sužava, završetak mu je oštećen, na vrhu je ušica za vješanje izrađena lijevanjem.

Literatura: R. KOŠČEVIĆ, 1991, T. XIII, 199; Ch. UNZ, 1974, 39, sl. 11, 130; B. NEDVED, 1981, 157, sl. 2,71 .

7. Inv. 3913, privjesak konjske orme, Salona, bronca, druga polovica 1. st., 2. st. (T. II, 7), vis. $5,6 \mathrm{~cm}$, šir. $3,4 \mathrm{~cm}$, listoliki privjesak postupno se sužava prema donjem dijelu, završava kuglastim ukrasom, ušica za vješanje nije sačuvana.

Literatura: A. VOIROL, 2000, 55, T. 13, 113; Ch. UNZ, G. DESCHLER-ERB, 1997, T. 54, 1477, 1478; J. OLDENSTEIN, 1977, T. 29, 190; A. K. LAWSON, 1978, 151, sl. 9,3; Ch. UNZ, 1974, 40, sl. 12, 138.

8. Inv. br. H 2619, privjesak konjske orme, Salona, bronca, druga polovica 1. st., 2. st. (T. II, 8), vis. $4,6 \mathrm{~cm}$, šir. $1,5 \mathrm{~cm}$, promjer karike $2 \mathrm{~cm}$, privjesak je gotovo rombičnog oblika, na vrhu je velika ušica kroz koju je provučena karika pomoću koje je privjesak bio obješen.

Literatura: R. KOŠČEVIĆ, 1991, T. XIII, 205; Ch. UNZ, 1974, 39, sl. 12, 141, 143; G. MANIÈRE, 1966, T. I, 17.

9. Inv. br. H 1385, privjesak konjske orme, Salona, bronca, prve dvije trećine 1. st.(T. II, 9,)

vis. $7 \mathrm{~cm}$, šir. $3 \mathrm{~cm}$, donji dio privjeska je u obliku bikove glave, sačuvan uložak od modrog stakla u desnom oku, iznad glave je privjesak oštećen, te nedostaju krakovi lunule, sačuvan je samo središnji dio iznad kojeg je okrugla ušica za vješanje.

Literatura: Ch. UNZ, G. DESCHLER-ERB, 1997, T. 58, 1630.

10. Inv. br. 3596, privjesak konjske orme, Salona, bronca, prve dvije trećine 1. st. (T. II, 10), vis. $4,2 \mathrm{~cm}$, šir. $7,1 \mathrm{~cm}$, na jednom kraju privjesak završava u obliku šake, a na drugom u obliku falusa, $\mathrm{s}$ donje strane su tri izdanka, a s gornje je četvrtasta ušica.

Literatura: M. FEUGÈRE, M. POUX, 2001, 83, sl. 5, 22; A. VOIROL, 2000, 54, T. 12, 102; A. K. LAWSON, 1978, 150, sl. 9, 12; Ch. UNZ, 1972, sl. 7, 71; P. LEBEL, 1959, T. LXI, 6; G. BEHRENS, 1918, 29, sl. 10, 6 . 


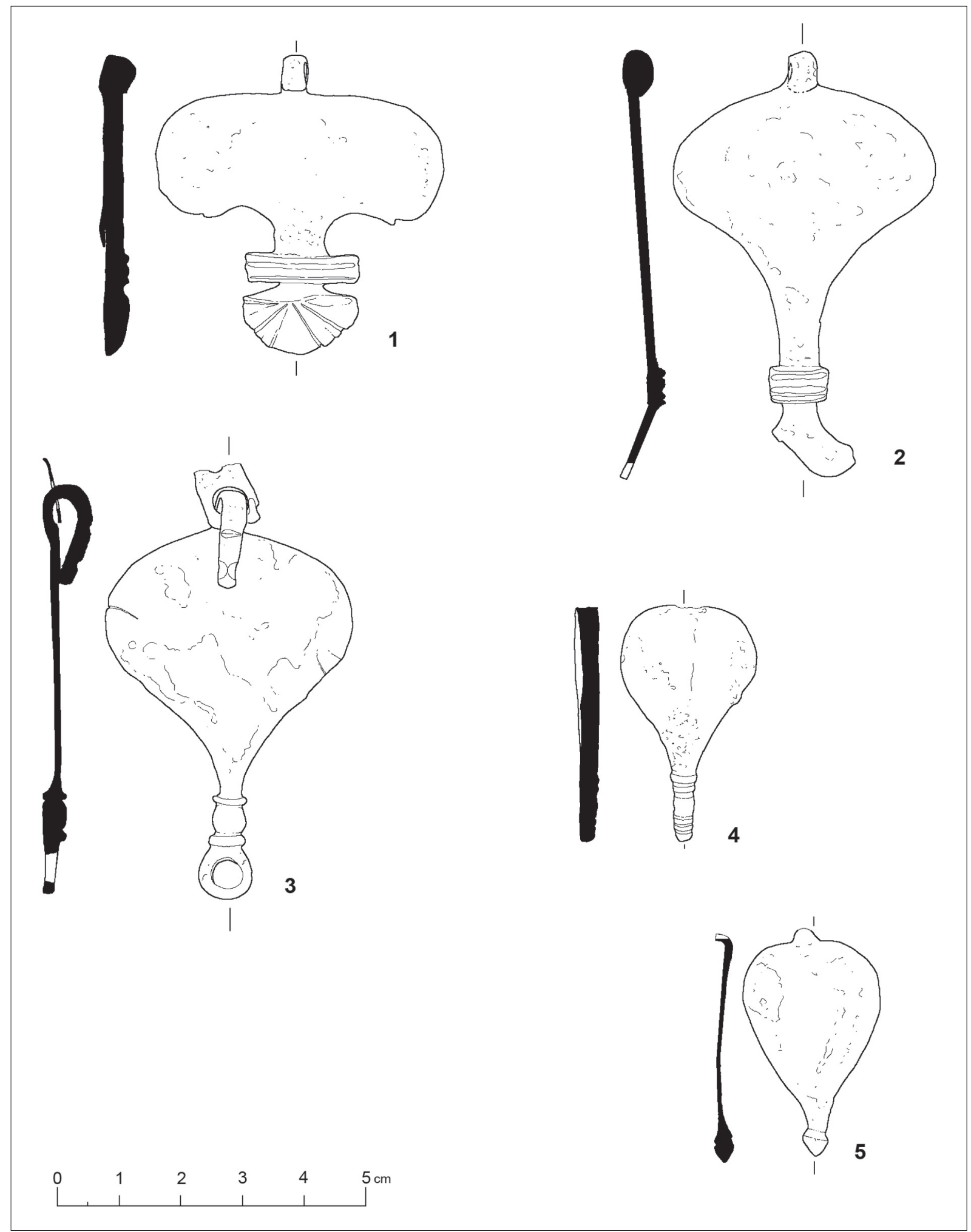

T. I. / Tab. I. 


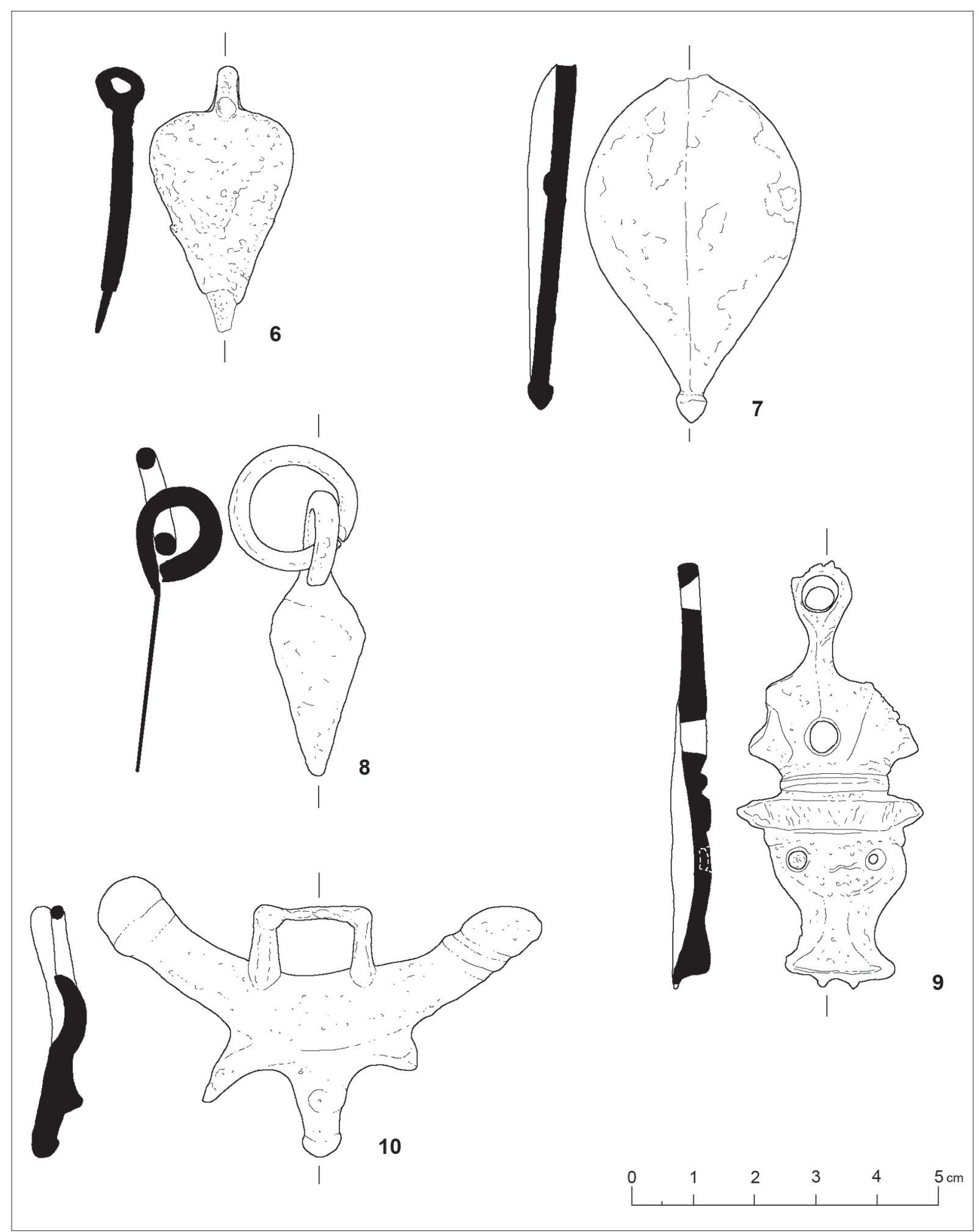

T. II. / Tab. II. 


\section{LITERATURA}

BEHRENS, G., 1912. - Gustav Behrens, Neue Funde aus dem Kastell Mainz, Mainzer Zeitschrift, VII, Mainz, 82-109.

BEHRENS, G., 1918. - Gustav Behrens, Neue und ältere Funde aus dem Legionskasstel Mainz, Mainzer Zeitschrift, XII/XIII, Mainz, 21-66.

BISHOP, M. C., 1987. - Michael C. Bishop, The Evolution of Certain Features, British Archaeological Reports, International Series, 336, Oxford, 109-139.

BISHOP M. C., 1998. - Michael C. Bishop, Cavarly equipment of the Roman army in the first century A. D., British Archaeological Reports, International Series, 394, Oxford, 67-195.

BOUBE-PICCOT, C., 1964. - Christiane Boube-Piccot, Phalères de Maurétanie tingiane, Bulletin d'archeologie Marocaine, V, Tanger, 145-199.

ČREMOŠNIK, I., 1984. - Irma Čremošnik, Rimski castrum kod Doboja, Glasnik Zemaljskog muzeja Bosne i Hercegovine u Sarajevu, 39, Sarajevo, 23-84.

FAHR, R., 2005. - Robert Fahr, Frühkaiserzeitliche militärausrüstung vom Gelände eines Feldlagers aus dem Bataverausfstand, Carnuntum Jahrbuch 2005, "Archäologie der Schlachtfelder - Militaria aus Zerstörungshorizonten", Akten der 14. Internationalen Roman Military Equipment Conference, August 2003, Beč, 109-136.

FEUGÈRE, M., POUX, M., 2002. - Michel Feugère, Matthieu Poux, Gaule pacifièe, Gaule libèrèe? Enquête sur les militaria en Gaule civile, Gesellschaft Pro Vindonissa, Jahresbericht 2001, Brugg, 79-95.

IVČEVIĆ, S., 2003. - Sanja Ivčević, Antički metalni predmeti iz Narone, u: Arheološka istraživanja u Naroni i dolini Neretve, Izdanja Hrvatskog arheološkog društva, 22, Zagreb-Metković-Split, 129167.

IVČEVIĆ, S., uz prilog VIŠIĆ-LJUBIĆ, E., 2004. - Sanja Ivčević, uz prilog E. Višić-Ljubić, The Metal and Bone Objects, u: The Rise and fall of an Imperial Shrine, Roman Sculpture from the Augusteum at Narona, (E. Marim, M. Vickers, ur.), Split, 235-243.

IVČEVIĆ, S., 2005. - Sanja Ivčević, Dijelovi opreme rimskog vojnika iz Garduna, Opuscula archaeologia, 28, Zagreb, 159-176.

JILEK, S., 2005. - Sonja Jilek, Militaria aus einem Zerstörungshorizont im Auxiliarkastell von Carnuntum, Carnuntum Jahrbuch 2005, "Archäologie der Schlachtfelder - Militaria aus Zerstörungshorizonten", Akten der 14. Internationalen Roman Military Equipment Conference, August 2003, Beč, 165-180.

KOHLERT-NÉMETH, M., 1988. - Maria Kohlert-Németh, Römische Bronzen I aus Nida-Heddernheim Götter und Dämonen, Archäologische Reiche, 11, katalog, Frankfurt.

KOŠČEVIĆ, R., 1991. - Remza Koščević, Antička bronca iz Siska, Umjetničko-obrtna metalna produkcija iz razdoblia Rimskog Carstva, Zagreb.

KOŠČEVIĆ, R., 2003. - Remza Koščević, Arheološka zbirka dr. Damir Kovač, u: Falosom protiv uroka, Arheološka zbirka dr. DamirKovač, Zagreb, 14-36.

LAWSON A. K., 1978. - Annabel K. Lawson, Studien zum römischen Pferdegeschirr, Jahrbuch des römisch-germanischen Zentralmuseums Mainz, 25, Mainz, 131-172.

LEBEL. P., 1959. - Paul Lebel, Les bronzes figurés, Catalogue des Collections archéologiques de Besancon $\mathrm{V}$, Annales littéraires de l'Université de Basancon, 26, Pariz.

MACKENSEN, M., 1991. - Michael Mackensen, Frühkaiserseitliches Pferdegeschirr aus Thamusida, Germania, 69/1, Mainz, 166-175.

MANIÈRE, G., 1966. - Gabriel Manière, Puits funéraire de la fin du Ier siècle aux Aquae Siccae (Cazères, Haute-Garonne), Gallia, XXIV, Paris, 101-146. 
NEDVED, B., 1981. - Branka Nedved, Nakit rimskog razdoblja, katalog, u: Nakit na tlu sjeverne Dalmacije od prapovijesti do danas, (ur. Š. Batović), Zadar, 151-182.

OLDENSTEIN, J., 1976. - Jürgen Oldenstein, Zur Ausrüstung römischer Auxiliareinheiten, Bericht der Römisch-Germanischen Kommission, 57, Mainz, 49-284.

RABEISEN, E., 1990. - Elisabeth Rabeisen, La production d'equipment de cavalerie au 1er s. après J.-C. à Alesia (Alise-Sainte-Reine, Côte d'Or, France), Journal of Roman Military Equipment Studies, 1, Oxford, 74-98.

RADMAN-LIVAJA, I., 2004. - Ivan Radman-Livaja, Militaria Sisciensia, Nalazi rimske vojne opreme iz Siska u fundusu Arheološkog muzeja u Zagrebu, Zagreb.

RITTERLING, E., 1913. - Emil Ritterling, Das frührömische Lager bei Hofheim im Taunus, Wiesbaden.

STUPPNER, A., 2002. - Alois Stuppner, Rinvenimenti germanici a nord di Carnuntum, u: Roma sul Danubio, Da Aquileia a Carnuntum lungo la via dell'ambra, ur: M. Buora, W. Jobst, Udine, 21-32.

ŠEPAROVIĆ, T., 2003. - Tomislav Šeparović, Metalni nalazi, u. Mirjana Sanader, Tilurium I, Istraživanja 1997.- 2001., Zagreb, 219-256.

UNZ, Ch., 1972. - Christoph Unz, Römische Militärfunde aus Baden - Aquae Helveticae, Gesellschaft pro Vindonissa, Jahresbericht 1971, Brugg, 41-58.

UNZ, Ch., 1974. - Christoph Unz, Römische Funde aus Windisch im ehemaligen Kantonalen Antiquarium Aarau, Gesellschaft pro Vindonissa, Jahresbericht 1973, Brugg, 11-42.

UNZ, Ch. - DESCHLER-ERB, E., 1997. - Christoph Unz - Eckhard Deschler-Erb, Katalog der Militaria aus Vindonissa, Veröffentlichungen der Gesellschaft pro Vindonissa, XIV, Brug.

VOIROL, A., 2000. - Annick Voirol, "Etats d'armes". Les militaria d'Avenches/Aventicum, Bulletin de l'Association Pro Aventico, 42, Avenches, 7-92. 


\section{Pendants on Roman Horse Equipment from Salona}

\section{SUMMARY}

Pendants hung from horse harnesses had a decorative, but also symbolical role, as they protected the animal from evil influences. They were utilized during the $1^{\text {st }}$ and $2^{\text {nd }}$ centuries $\mathrm{AD}$ and are frequent finds throughout the Roman Empire.

The examples from Salona can be classified into three basic types according the typology of Bishop.

Two are examples of type Bishop 2 a (cat. 1,2 ), dated to the $1^{\text {st }}$ century. The most represented type is Bishop 5e, with six examples, including the most interesting pendant (cat. 3), as it exhibits a connection to the so-called bird-like pendants (Bishop 7), and is typologically located between the two types. In contrast to the pendants whose characteristics correspond to the basic form of type 5e (cat. 4-7), a rhomboid pendant (cat. 8) stands out somewhat in terms of shape. This type is dated somewhat later than the previous one, from the mid $1^{\text {st }}$ century to the end of the $2^{\text {nd }}$ century. Type Bishop 10 is represented with two examples but of different variants. The example with a bull's head (cat. 9; Bishop 10c) is analogous to such pendants found in other parts of the Empire, and as they are scarce yet similar, it is conjectured that they were produced in the same workshop, located in the region of northern Italy. A lunular phallusoid pendant (cat. 10) exhibits certain specificities of form (square loop and distinct stylization), and it is assigned to the variant that is most similar (Bishop 10r). They are dated to the $1^{\text {st }}$ century.

The formation and manner of decorating the pendants of horse harnesses exhibit a certain uniformity, and they can be divided into a limited number of types. At the same time they display a variety of expression, which was evidently caused by production in numerous workshops, and to a certain extent by the origin and tradition of the user. The quantitative and typological analysis of the pendants, or parts of horse equipment, from a broader area, for instance the province of Dalmatia, along with knowledge and study of the movement and residence of military units of varied ethnic origin in this territory, and the eventual establishment of workshop units for the manufacture of military material, represent preconditions for studying the military history of this region.

KEY WORDS: pendants, Roman horse equipment, Salona 